\title{
Research on Application of Music Games in Class Teaching of Music in Primary School
}

\author{
$\mathrm{Na} \mathrm{Li}$ \\ Linyi University Feixian Campus \\ Feixian, China 273400
}

\author{
Huihua Liu \\ Linyi University Feixian Campus \\ Feixian, China 273400
}

\begin{abstract}
The game is a favorite teaching activity for music teachers and students in primary schools. Game teaching is an effective way to stimulate pupils' interest in music learning. This paper is based on the investigation and research of music classroom teaching in primary schools. Aided by the theory of primary education, it emphasizes on the use of games in music classes. In view of the application situation of game teaching in music teaching of primary school, the authors put forward and analyze some suggestions from several aspects: the feasible strategies of using music games teaching to promote pupils' learning, the application principles of music games in music class teaching of primary school, and the improvement measures of combining music games teaching with other teaching modes to promote the optimization of music teaching.
\end{abstract}

Keywords-game; music of primary school; teaching strategy; application

\section{INTRODUCTION}

From the perspective of learning methods suitable for the students of primary schools, the learning, life and games of pupils can be combined. The application of music games in music classroom teaching of primary school can stimulate pupils' interest in learning music, cultivate pupils' innovative abilities, and stimulate students' exploration spirit. Music class games of primary school are good means for primary school students' moral education, aesthetic education, imagination enhancement, cognitive ability, ability to enrich music knowledge, and development of intelligence. However, in the specific teaching practice, it is necessary to truly attract pupils to actively participate in the activities. And it would encourage pupils to continuously increase the level of participation in music activities and enjoy music.

\section{PROBLEMS IN THE APPLICATION OF GAME IN MUSIC ClassroOM TEACHING OF PRIMARY SCHOOL}

Game teaching has achieved certain development in China. And game teaching has changed the traditional teaching model of "cramming with a full house". And it has inspired the interest of most primary school students. The primary school students would participate in teaching activities over time. More and more, passive indoctrination learning is actively involved in teaching activities. In addition, in the process of using game teaching, the learning atmosphere and classroom discipline are obviously better than traditional music teaching. Specific to students, game teaching would make the students have changes from passive acceptance to active understanding. And the students would feel the joy of cooperative learning. The game teaching is more suitable for primary school students' classroom learning. On the other hand, game teaching needs flexible and changeable organization guidance. And it is also gradually increasing the ability of music teachers to control the classroom. The teachers must actively think about the ways to organize classroom teaching. In some school music lessons that are randomly listened to, most music teachers and students are able to form good interactions. They can also use game teaching methods more skillfully and can complete teaching goals in a limited time.

From the perspective of dialectic, any problem in the world will be divided into two. And music games have no exception. The authors learned from the field investigation, discussion and observation. With the introduction of the game into the music class, it can really make up for the boring deficiencies in traditional music teaching. However, some frequent and random game activity also can bring the bad influence to the normal teaching. In the teaching, it also has some insufficiency and questions. And some teachers pursue the active classroom atmosphere. The teaching process seems to be lively. And it has not included the difficult points. It does not make the distinction from the primary and secondary. Actually, it neglected the validity of classroom teaching. The reasons can be shown in the following.

\section{A. The Level of Music Game Teaching Is Uneven, the Quality of Teaching Has a Significant Reduction}

Some of music teachers in the elementary school believe that the task of music teaching is to lead students to sing in their own ideas. And then, they do not pay much attention to improving the quality of music teaching. In addition, some schools are short of music teachers. Some non-music teachers work part-time in music lessons. They have not studied the professional teaching skills of music games and even do not understand them at all. And they can't improve the quality of music classroom teaching. Third, most parents only pay attention to the study of the general knowledge course. In this case, the pupils like music classes. However, with the heavy pressure of the culture course, the pupils' good study habit has not yet formed. It is difficult to control the discipline of music class. And the music teachers would gradually have the occupation burnout with the increase of 
the teaching age. And then, the teaching quality would drop gradually. They may arrange the teaching activities at will. It certainly affects the pupils' actual study effect.

\section{B. It Is Difficult to Accurately Grasp the Progress of Teaching in Music Game Teaching}

In the actual teaching process, some music games have a simpler design structure and less knowledge content, such as music knowledge, leisure and puzzle games. And the primary school students can successfully complete the game within a short time with the guidance of teachers. Teaching progress can be smoothly controlled. However, when encountering music games such as role-playing and scenario simulations, the plot becomes more complicated and the carrying capacity has increased. And the pupils need much time to complete the entire game. It is difficult for teachers to grasp more accurate teaching schedules and affect the overall teaching effect.

\section{To Arrange Games in Music Teaching Blindly, and to Lose the Practical Effect of Teaching}

In class, we advocate game-style music teaching. The goal is to complete the tasks more efficient and better. Instead of playing the classroom atmosphere, neglecting the knowledge of music teaching, and blindly playing for the game, such results would make the game-style teaching lose the significance of learning knowledge. In addition, some teachers believe that they should pay attention to the students. And the teachers should always pay attention to the performance of students in the classroom. The students should actively speak and enthusiastically perform in the classroom. The teachers should strive to make every student happy to learn. This is not wrong in teaching theory. When the form is active, the teachers can't master the "degree" between the game and the learning relationship. And then, it would have new problems. The teachers can't grasp the dialectical and unified relationship between students' learning knowledge and the interest of learning in interesting games. It seems that a class is very busy and interesting. The pupils are also very lively. However, they have not allowed primary students to learn substantive knowledge. In the end, the teaching methods wouldn't be practically efficient.

\section{THE IMPROVEMENT OF MUSIC TEACHING GAMES IN PRIMARY SCHOOLS}

\section{A. To Have the Concept of Lifelong Learning and Continuously Strengthen the Cultivation of the Overall Quality of Music Teachers}

With the development of national education and the advancement of music education reform, basic music education is also constantly pursuing new goals. And the society has increasingly higher requirements for the overall quality of music teachers. The teaching ability of the instructor is closely related to the success of music lesson. Music teachers must use various teaching methods in teaching. Then, they would successfully carry out classroom teaching activities and ensure the completion of teaching tasks. Through questionnaires and individual interviews with elementary school students, parents, teachers, and music education experts of elementary school in surrounding areas, combined with more than 20 years of experience in "music teaching method" courses, we have found that in the actual music classroom, games can be used. The teaching of music is not very common. The appearance of these problems has a certain relationship with the teaching ability of coaches. A qualified music teacher must possess certain game-based teaching skills after having the basic qualities of teachers. He wants to love game-style music teaching. There is a special perception of this. When leading the students to sing a song, they must have full emotions. When they enjoy music, they must show a strong interest. Only teachers who are teaching themselves will be moved. It may lead students to become infected and complete their teaching goals.

In addition to professional teaching ability, primary school music teachers also need to master certain general education theories and abilities. In teaching, the students have individual differences. And there must have different understandings of the same thing. Some students may understand it when hearing it once. And the others will need a little longer time to understand. At this time, music teachers need to think about how to teach students in accordance with their own educational theory knowledge. If the students' ability to accept is really slow, the simple and harsh reprimand will inevitably hurt the students' self-esteem. And it will also reduce the enthusiasm of learning music. And it may even result in negative psychological tendency to exclude music classes. As music teachers in primary schools, they need to master a certain amount of pedagogy and psychology knowledge. Also, they should be able to actively practice with the game teaching theory. In the end, the game could better play the teaching function. All music teachers of elementary schools should continue to learn, improve their own comprehensive coaching ability, always hold the concept of lifelong learning, and actively carry out teaching reflection after each music lesson. And they would achieve better teaching results.

\section{B. To Pursue Music Games of Primary Schools Effectively and Require Adequate Preparation}

Before the game-style music teaching, the first task is to prepare lessons. To prepare lessons must first understand the teaching materials, the content of the teaching materials, the specific requirements of the teaching materials in terms of knowledge, skills and aesthetics, clarify the key teaching difficulties, and work out the lessons. And the teachers can complete this lesson. The practical teaching goals would be worked out. The music teachers are familiar with the content of the teaching. The teaching arrangements are also wellprepared. And then, it can meet the basic conditions for classroom teaching. Secondly, with the actual situation of the schools and students, teachers must adopt flexible and varied teaching programs, fully coordinate various aspects of the curriculum resources, and understand the students' existing musical skills and knowledge reserves in advance. The content of the primary school students may occur in this lesson. The points of interest should also be prepared to solve the anomalous problems that occur at any time. We 
must pay attention to avoiding the situation of "preparing textbooks" when students are not available in the preparation. In this way, teachers can only calmly and objectively focus on the actual teaching process. Third, when preparing lessons, we must also consider what kind of teaching content needs to be arranged for what kinds of games. The teachers should integrate teaching content into each other, and arrange appropriate games in the teaching process. It would mobilize students' enthusiasm for learning as much as possible. Finally, in the preparation, we must accurately grasp the key and difficult points of the teaching content. A successful music lesson should also consider the key difficulties for music teachers to break through the teaching content. In the music classroom, the teachers are regardless of the importance, and they would grasp eyebrows and beards. It is impossible to complete the expected goals of classroom teaching, and the teaching effect will naturally not be very good.

\section{CONCLUSION}

In short, the current concept of applying the game to music classroom teaching of elementary school is rapidly developing. And there are also some problems. It will not be resolved in the short term. And we need our educators to take the initiative to update their educational concepts. The teachers should learn, expand the field of vision, pay attention to after-school summaries, organize and record typical problems in a timely manner, and sort out the epiphanies in the class timely, information feedback of students, successful experiences and poorly thought-out issues, and follow the law of the development of music of the new era. They should have active try. In addition, this requires not only the improvement of the entire music teacher, but also the understanding and support of all walks of life. Only through such joint efforts, it will continue to explore and eventually solve various problems in the music teaching in primary schools. Thus, it would promote longterm development of music education.

\section{REFERENCES}

[1] Shen Jianzhou. Strategies to promote children's game education effectively [J]. Journal of Peking University Education, 2002(3).

[2] Xu Zhuoya. Preschool children's art education [M]. Shanghai: East China Normal University Press, 2007.10.

[3] Huang Jin. Game spirit and childhood education [M]. Nanjing: Jiangsu Education Press, 2006.

[4] Li Yao. How to use games in music teaching of elementary school [J]. Chinese School Education, 2013, (8): 165.

[5] Wu Jiayang. Let games play "Bridge of Happiness" to experience music better-Talking about the practice and feelings in music teaching of elementary school $[\mathrm{J}]$. China Youth (Study for Teen Education), 2013.(17) : 264.

[6] Dai Jianqiang. The important role of games in music teaching in primary schools [J]. Reading and Writing, 2015, (20) 